\title{
Assessing Barriers of Real Practicing Speaking Skills in EFL Classroom: The Case of Assosa University, Ethiopia
}

\author{
Merga Desalegn \\ Department of English Language and Literature, College of Social Science and Humanities, Salale University, Fitche, Ethiopia \\ Email: mergad470@gmail.com
}

How to cite this paper: Desalegn, $M$. (2020). Assessing Barriers of Real Practicing Speaking Skills in EFL Classroom: The Case of Assosa University, Ethiopia. Open Journal of Social Sciences, 8, 330-342. https://doi.org/10.4236/jss.2020.83030

Received: January 22, 2020

Accepted: March 22, 2020

Published: March 25, 2020

Copyright () 2020 by author(s) and Scientific Research Publishing Inc. This work is licensed under the Creative Commons Attribution International License (CC BY 4.0).

http://creativecommons.org/licenses/by/4.0/

\section{(c) (i) Open Access}

\begin{abstract}
This study assessed barriers of real practicing speaking skills during EFL sessions at Assosa University, college of social science first-year students in focus. To achieve the objectives of the study, questionnaire, interview and observation were employed to collect data from the respondents. The data collected through questionnaire were analyzed using frequency and percentage whereas the data collected via interview and classroom observation were narrated qualitatively. The data obtained in different instruments were triangulated in order to check the reliability of the finding. The finding of the study suggested that majority of the students were not interested to use English daily, and there were the resistance of the learners not to speak in English as well as not to actively engage in collaborative learning. The result of the study also revealed that students had a negative perception towards the practice of speaking skills during EFL sessions. In general, students' background, unwillingness of the students to speak and students' resistance of active learning techniques were the major factors that influenced the real practicing of speaking skills during EFL sessions. Following the finding of the study, the recommendations were suggested in order to solve the problems encountered.
\end{abstract}

\section{Keywords}

EFL, ESL, Barriers, Assosa University, Ethiopia

\section{Introduction}

The learning of English speaking skill is a preference for a lot of English as Foreign/Second Language (EFL/ESL) learners. Learners sometimes evaluate their progress of language learning following how well they have brought an im- 
provement in their communicative skills. Teachers prefer to use the direct approach which focuses on the oral communication of the learners through giving group work, turn taking activities and other techniques (Richards, 1990).

The concern of language learning in the past was the mastery of grammatical knowledge where learners were mainly expected to know the grammatical rules. However, the use of grammatical knowledge in their day-to-day life was not given due to emphasis. Concerning about the traditional way of grammar-based teaching of language, Larsen-Freeman (1986) stated that the role of traditional grammar oriented language teaching is to focus on the language rather than the message delivered by the language. Here, the role of the teacher is simply to learn vocabulary and grammatical rule of the language.

However, today the primary aim is teaching the practical use of English for communication with native speaker and others. The foundation of communicative approach to language teaching has come to the field of language teaching which brings about a number of changes in traditional methods of language teaching. The main goal of communicative approach is communicative competence which gives attention to the use of the desired language for communicative purpose (Richards \& Rodgers, 2001, and Littlewood, 1981). Communicative is a word which has dominated discussions of teaching methodology for many years.

Therefore, to create effective speaking activities that will develop the students' communicative competence, a teacher needs to incorporate communicative activities in which learners can have plenty of opportunities to exchange information among themselves in the classroom as well as outside of classroom.

During teaching speaking, the main aim is to enhance English language proficiency of the learners (Davies \& Pearse, 2000). Similarly, Kedir (2017) stated that speaking English helps students to convey their information or to get message in any fields of study. This implies that through practicing English, students gain valuable skills which can help students in their day to day communication through the use of new vocabulary, grammar or functional language like: greeting and introductions.

Although speaking skill has such contribution in the use of the target language (English), in our country, the teaching of speaking is not given a significant place in English language teaching in the classrooms. Many teachers primarily focus on grammar and vocabulary for grammar and vocabulary are tested during examinations. Due to this speaking is a forgotten skills during delivery of the sessions. Consequently, this neglection of the speaking skills results in difficulty to speak English outside the classroom. Hence, having this misconception about the role of speaking skills, some teachers have continued to teach speaking skill as the repetition of drills or memorization of dialogues. In other words, it is taught in the way it cannot develop students speaking ability as Demissie (2007) stated in his study. It is also stated that students lack opportunities to practice speaking English language. Most of the time students are expected to follow 
teacher fronted lessons and the only chance they have to utter a word or phrase is when they are asking and answering questions. This may not contribute much to developing the ability to speaking well. In this regard, Rivers (1983) stated that students do not learn to speak a language fluently by continual practice in question and answer on literary text, a very common procedure in foreign language classes.

Even though it is about a long period, since communicative approach of teaching a language introduced in Ethiopia, the teaching of speaking in the country still follows the traditional method of teaching which is teacher-centered. In most cases, it remained to be the teaching of language rules instead of language uses. As a result, the entire teaching activities especially that of speaking failed to be effective. Thus, learners at all levels of education in the country experience deficiency of spoken language. Similarly, from the experience of teaching at Assosa University for six years, I observed that most students were unable to express their ideas to someone easily. When the learners were requested to discuss the activities given in the classroom with their colleagues in English, they were reluctant to do so, and they preferred to use the local language. Even when they were motivated to express their views in English, they couldn't construct a meaningful sentence. Though some studies had been conducted concerning students improvement of speaking skills, the present day most students practice of teaching speaking skill and understanding is very low. But, there is no study conducted concerning barriers of real practicing of speaking skills at this particular area, Assosa University, college of social science in focus to alleviate the problem. Due to this, most students are not confident enough to share their ideas or express themselves in English. Therefore, this study was intended to fill this gap. As a result, this study was conducted to assess factors of real practicing speaking skills in EFL classroom at Assosa University, College of Social science and Humanities in focus. Hence, this study enables the students to have the right attitude towards the practice of speaking skills in order to improve their language proficiency, and it also helps the learners to be familiar with different techniques to practice speaking skills so as to improve their communicative skills. Curriculum designers and stake holders can be benefited in a way to get a direction on how to effectively solve the problems encountered during the implementation collaborative learning. To contribute for the aforementioned above, the study was intended to answer the main factors that hinder the practice of speaking skills during EFL sessions, to identify the perception of teachers and students towards practice of EFL speaking skills in the classroom and to examine the extent in which techniques of real practicing speaking skills implemented during EFL sessions.

\section{Methodology}

\subsection{The Study Area}

This study was conducted in Assosa University, Ethiopia. Assosa University was 
found in Benishangul Gumuz Regional State around $678 \mathrm{~km}$ far away from the center, Addis Ababa. In Assosa University, there were five Colleges. Those were College of Social Science and Humanities, College of Natural and Computational Science, College of Agriculture and Natural Resources, College of Business and Economics and College of Health Science. Among the five colleges, the researcher selected only College of Social Science and Humanities purposely since the researcher knew students of the college closely. In the College of Social Science and Humanities, there were five departments. From those five departments, the researcher selected randomly three departments to be considered as respondents of the study. Those departments were: Department of English Language and Literature, Sociology and Civic and Ethical Studies. Simple random sampling technique was applied so as to maintain equal chance of being selected for the whole departments under the College of Social Science and Humanities.

\subsection{Population and Sampling Techniques}

There were a total of 350 students and 18 English Language teachers within the three selected departments: Department of English Language and Literature, Sociology and Civic and Ethical Studies. Among 350 students, the researcher selected 205 students from the three departments. The sample size for this study was determined by using Yamane (1967) formula.

$$
n=\frac{N}{1+N(e)^{2}}=\frac{350}{1+\left(350 \times 0.045^{2}\right)}=205
$$

where $n=$ designates the sample size, $N=$ designates total number of students taking Communicative English skills in the College of Social Science and $\mathrm{Hu}-$ manities (350) and $e=$ designates maximum variability or margin of error (4.5\%). And also the whole 18 language teachers were selected based on the availability sampling method.

\subsection{Methods of Data Collection}

To collect data from the participants of the study, the researcher employed three methods of data collection techniques: questionnaire, interview and classroom observation.

\section{Questionnaire}

The questionnaire was used as method of data collection for it helps to gather a variety of data from the large populations easily. In this questionnaire, both close and open ended questions were included. The close ended questions were rated based on the liquert scale, and it also included yes or no items. And the open ended questions could enable the researcher to obtain extended ideas from the respondents concerning their reactions to the questions. In this questionnaire, different questions were developed so as to dig out the challenges in practicing speaking skills from the selected departments. Hence, the questionnaire was distributed to 205 students and 18 teachers. 


\section{Interview}

Interview was also one of the instruments that the researcher used in order to collect data from the respondents. Hence, the researcher held an interview with the three department heads of the selected department and college dean of college of Social Science and Humanities. Interview was also held with five voluntary teachers. During the interview, the researchers adjusted convenient time and place in which the interview was held.

\section{Observation}

The classroom observation is one of the important tools in order to collect data from our participants since it gives the full sense of the existing situations that take place during the actual teaching-learning process. As a result, the researcher employed classroom observation in order to achieve these goals. For classroom observation, one section was selected from each department. Hence, three sections were observed from the six sections for observing each session was too difficult and time consuming. Within the selected sections, the observation was held for a week having a check list questions in order to really observe the actual practice of speaking and its challenges. The classroom observation was basically conducted to check whether there was real practice of speaking skills or not during EFL sessions. Hence, observation was performed having checklists which focused on activities set by the teacher during the session, the extent in which students were taking part during the session and their perception toward classroom participation, roles of teacher and students and the overall situations to really practice speaking skills.

\subsection{Methods of Data Analysis}

After the data collected from sample respondents, the researchers employed both quantitative and qualitative methods. The data collected through questionnaire were analyzed using frequency and percentage whereas the qualitative method was used for the data collected via interview and observation.

\section{Results and Discussion}

\subsection{Students Response to the Barriers of Practicing Speaking Skills}

As indicated in Table 1 below, students were asked different questions concerning factors that influence the presence of real practice of speaking EFL in the classroom. Accordingly, the majority of the respondents (69.75\%) revealed that they had no exposures that encourage them to really practice during the delivery of the lesson. Similarly, during classroom observation I observed as the students had no more experience to actively engage in the activities that the teacher gave them. When the teacher gave students a task to discuss so as to improve their speaking ability, majority of the students were acting as if they were not as such familiar with the activities to discuss. This implied that learners had not been given a conducive environment to practice speaking EFL inside and outside the 
Table 1. Students' response to the barriers of practicing speaking EFL.

\begin{tabular}{ccc}
\hline Barriers & Frequency (N) & Percent (\%) \\
\hline Fear of Feedback during speaking & 137 & 66.83 \\
Topical knowledge & 78 & 38.05 \\
Exposure & 143 & 69.75 \\
Motivation to speak & 187 & 91.22 \\
Vocabulary problem & 95 & 46.34 \\
Lack of confidence & 112 & 54.63 \\
Anxiety & 103 & 50.24 \\
Listening ability & 117 & 57.07 \\
\hline
\end{tabular}

Note that a single respondent was allowed to choose more than one barrier.

classroom. Similarly, $66.83 \%$ of the respondents confirmed that because of the fear of feedback during speaking, they were not voluntary to share their ideas easily when the teacher gave them an activity to participate.

Listening ability and lack of confidence were also another factor that hinders the respondents not to actively engage or practice speaking skills in the classroom. So that $57.07 \%$ and $54.63 \%$ of the respondents respectively had no listening ability and confidence. Listening, according to the study of Tamador \& Snoubar (2017) is the skill that receives the least attention in EFL classes in Jordan. This happened due to the following two reasons. The first reason is that teachers perception as teaching listening skills can be covered within teaching of reading. But this idea is against the idea of Gilakjani and Ahmadi (2011), Bozorgian (2012), Celik \& Yavuz (2015). The second one reason emphasize on the procedures required to teach and test listening skills. Moreover, (Tuan \& Mai, 2015) state that learners oral performance is affected by listening skills. From this, we understand that listening, which is considered as the mother of the speaking is not given due emphasis in the classroom in order to enable the learners to develop their communicative ability.

In the same table, 78 (38.05\%) of the respondents stated that there was no real practice in EFL classroom due to the problem of topical knowledge. This shows that expecting learners to speak in English when they are not familiar with the topic is unexpected. As a result, there was no real practice of speaking skills in the classroom when they had given unfamiliar topics to reflect or share issues with one another.

Vocabulary problem was also perceived as an influencing factor of the practice of speaking skills in the classroom. Hence, 95 (46.34\%) of the respondents agreed that they faced vocabulary problem during speaking with other colleagues. This result confirmed the ideas stated by Urrutia \& Vega (2010). As they stated students speaking proficiency is affected by their insufficient vocabulary. Therefore, vocabulary was also one factor that hindered them not to easily understand someone's message. As half of the respondents, $50.24 \%$ of them responded, anxiety 
was also the hindering factor. This result confirms the idea of Horwitz, Horwitz, \& Cope (1986), adult language learners prevalently feel anxious during their learning experience, and it often makes foreign language learning a very inconvenient experience for them. In addition, difficulty in speaking in EFL classes is probably the most frequently-cited concern of the anxious EFL students seeking help from either their peers or teachers.

In Table 1 above, students were also asked about motivation to speak as one factor of influencing the learners' speaking skills in the classroom whether it influenced them or not. As the respondents said, there was no the presences of real practice of speaking skills in EFL sessions for $91.22 \%$ of the students were not interested to speak in English. This implies that without motivation to speak, students will not actively participate or share their own ideas during teachinglearning process. This result contradicts with the view of Brown. The learners attitude in improving the foreign language is undeniable (Brown, 2000). Furthermore, Gardner (2006) also stated that learners with high level of motivation can do better than the one who has less motivation. He also said "if one is motivated, he/she has reasons (motives) for engaging in the relevant activities, expends effort, persists in the activities, attends to the tasks, shows desire to achieve the goal, enjoys the activities, etc.".

\subsection{Teachers Response to the Barriers of Practicing Speaking Skills}

As can be seen in Table 2, teachers were also asked the different factors that might influence the practice of speaking skills in EFL class. Accordingly, the majority of the respondents, 17 (94.44\%) of them replied as the learners background was greatly influencing the implementation of the speaking skills in the classroom. In line with this idea, most teachers also responded during interview with them as the students' background of teaching-learning process affects the intention to implement the different active learning methods in order to enable the learners to practice speaking skills in the classroom. Similarly, $83.33 \%$ of the respondents also stated that their students were resisting the practice of speaking skills in EFL class. In addition to this, during the researcher observation of the classroom, I seriously saw the students' lack of interest not to actively engage in the activities distributed to them. When the teacher gave them an activity ex-

Table 2. Teachers' response to the barriers of practicing speaking EFL.

\begin{tabular}{ccc}
\hline Barriers & Frequency (N) & Percent (\%) \\
\hline Class size & 18 & 88.88 \\
learners resistance & 15 & 83.33 \\
Curriculum & 14 & 77.77 \\
Time & 9 & 50 \\
Learners background & 17 & 94.44 \\
Flexibility of chairs & 13 & 72.22 \\
\hline
\end{tabular}


pecting them to share a lot of ideas in the classroom, most of the students were not even voluntary to form a group immediately. Therefore, I didn't observe the good practice of students due to their resistance to actively engage in the activity. This implies that students were passive during EFL sessions, and learners were not interested in the practice of speaking skills so as to improve their communicative English skills.

As indicated in Table 2 above, 18 (88.88\%) of the respondents confirmed that class size was also the most influencing factor of practicing speaking skills in EFL sessions. In the same way, I also observed that classroom was not conducive to apply active learning methods because of the availability of large numbers of students in the classroom. When the teacher tried to give them activities to discuss, the presence of many students within a classroom was affecting the real practice of speaking skills in EFL sessions, and it was difficult for the teacher to easily supervise or assist all learners during delivery of the sessions.

Curriculum and flexibility of the chair were also among the factors influencing the real practice of speaking skills in EFL class. So that $77.77 \%$ of the respondents confirmed that curriculum itself was a hindering factor. During interview, teachers also complained on the way in which the material designed was not given due emphasis on the real practice of speaking skills rather it focuses on teaching grammar. Hence, most part of the teaching material doesn't encourage the learners-centered approaches.

Time was also among the other factors of hindering the implementation of speaking skills during EFL sessions. Accordingly, half of the respondents said that time was one of the factors that hinder the real practice. Similar with this idea, during teachers' interview, most of the respondents reported that implementing the learner-centered approach in order to enable the learners to actively practice speaking skills in EFL session was time consuming. As most teachers said, if we try to apply fully the active learning techniques in the classroom, we couldn't cover the contents of the material since it is bulky.

\subsection{Perception of Students towards Practicing Speaking Skills}

As stated in Table 3 below, different points of view concerning the perception of the students in relation to the real practice of speaking skills in EFL sessions were given in order to identify how the perception of the students can affect the real practice of speaking in the classroom.

As stated in Table 3 below. Accordingly, 51 (24.87\%) of the respondents strongly disagreed on the idea that said practicing speaking skills in the classroom helps me to be an effective student. And also 97 (47.53\%) of the replied as they disagree. This indicates that the majority of the respondents $(72.22 \%)$ had a negative perception on the idea. This reveals that learners are not aware of the value of practical implementation. In this regard, Muhammad in his study had a similar idea. Hence, a study held in UIN Sunan Kalijaga Yogyakarta, 
Table 3. Perception of students to practice speaking skills in EFL sessions.

\begin{tabular}{|c|c|c|c|c|c|c|c|c|}
\hline \multirow{3}{*}{$\begin{array}{l}\text { What do you feel about the following } \\
\text { points? }\end{array}$} & \multicolumn{8}{|c|}{ Rating scales } \\
\hline & \multicolumn{2}{|c|}{1} & \multicolumn{2}{|c|}{2} & \multicolumn{2}{|c|}{3} & \multicolumn{2}{|c|}{4} \\
\hline & $\mathrm{N}$ & $\%$ & $\mathrm{~N}$ & $\%$ & $\mathbf{N}$ & $\%$ & $\mathbf{N}$ & $\%$ \\
\hline $\begin{array}{l}\text { Practicing speaking skills in the classroom } \\
\text { helps me to be an effective student }\end{array}$ & 51 & 24.87 & 97 & 47.35 & 35 & 17.07 & 22 & 10.73 \\
\hline $\begin{array}{l}\text { I think practicing speaking skills daily is } \\
\text { the best way to learn a language }\end{array}$ & 78 & 38.04 & 84 & 40.97 & 36 & 17.56 & 7 & 3.41 \\
\hline $\begin{array}{l}\text { I can develop my confidence through } \\
\text { practicing daily }\end{array}$ & 49 & 23.90 & 66 & 32.19 & 59 & 28.78 & 31 & 15.12 \\
\hline $\begin{array}{l}\text { I prefer cooperative learning to improve } \\
\text { my communicative skills }\end{array}$ & 82 & 40 & 73 & 35.60 & 28 & 13.66 & 22 & 10.73 \\
\hline $\begin{array}{l}\text { Daily practicing speaking in the classroom } \\
\text { is wastage of time }\end{array}$ & 19 & 9.27 & 32 & 15.60 & 71 & 34.63 & 83 & 40.49 \\
\hline $\begin{array}{l}\text { I can understand more if I practice with } \\
\text { my colleagues }\end{array}$ & 88 & 42.92 & 62 & 30.24 & 35 & 17.07 & 20 & 9.76 \\
\hline $\begin{array}{l}\text { I don't like to practice since I am not } \\
\text { perfect enough in English }\end{array}$ & 9 & 4.4 & 14 & 6.83 & 87 & 42.43 & 95 & 46.34 \\
\hline
\end{tabular}

Key: strongly agree $=4$, agree $=3$, disagree $=2$, strongly disagree $=1$.

Indonesia by Muhammad (2014) stated that the students of English department in the university were aware about the importance of English language for their future. However, learners awareness didn't show their attitude. But, few of the respondents stated their feeling as they had a positive view to engage on it. In this way, among the total sampled respondents, $27.8 \%$ of them revealed that practicing speaking skills enable them to be an effective teacher.

In the same table, most respondents didn't perceive that practicing speaking daily was not the best way to learn a language. As a result, 78 (34.04\%) and 84 (40.97\%) of them strongly disagreed and disagreed respectively. This showed that averagely most respondents were not comfortable with the idea that practicing speaking skills was the best way to learn a language. But few of the respondents $(20.97 \%)$ replied for this item as they agreed that practicing speaking skills daily was the best way to learn a language. Similarly in the same table above, students were also asked to indicate their perception on the relationship between developing confidence and daily practicing speaking. Hence, $59(28.78 \%)$ and $31(15.12 \%)$ of the learners agreed and strongly agreed respectively as they could develop their confidence through daily practicing. Contrarily, more than half of the respondents which were $56.09 \%$ of them had a negative perception to the relationship between daily practice and developing one's confidence.

As also seen in the above Table 3, students were asked to state their feeling in relation to the preference of cooperative learning so as to improve their communicative skills. In this regard, 82 (40\%) of them strongly sated as they didn't prefer cooperative learning to be implemented. $73(35.60 \%)$ of them also stated as 
they disagreed on the idea that I prefer cooperative learning to improve communicative skills. But, some of the respondents, which were less than half of them stated as they prefer cooperative learning to improve their communicative skills. In line with this, during my classroom observation the researcher observed as most of the learners were not as such interested in the implementation of cooperative learning. Though the teacher gave a lot of activities so as to enable the learners to share their ideas together during delivery of the session, the researcher didn't observe an active involvement of the learners in the given activities.

Students were also asked in the same table above concerning about the daily practice of speaking skills whether they perceived it as a good technique or not. Accordingly, about $9.27 \%$ of the respondents strongly disagreed and $15.60 \%$ disagreed on the issue of daily practicing speaking skills considered as wastage of time. This means that about $24 \%$ of the respondents perceived positively as daily practicing was not wastage of time. However, the majorities which were around one third of the respondents, 75\% disagreed on it. This implies that most of the learners negatively perceived daily practicing speaking skills in EFL sessions as wastage of time. Similar with this, the data of classroom observation revealed the resistance of the learners not to actively engage in the activities the teacher gave them in the classroom. Hence, the researcher observed from the situation of the classroom as the students were not comfortable with having daily practicing of speaking in the classroom.

As stated also in Table 3 above, 88 (42.92\%) of the sample respondents strongly disagreed on the statement that said I can understand more if I practice with my colleagues, and $62(30.24 \%)$ also disagreed on the given similar issue. The remaining few respondents, $26.83 \%$ only perceived positively as they can understand more if they practice with their colleagues. This indicates that the learners don't prefer learning from others which give them golden opportunities to improve their communicative competency.

The students were also asked about their perception to engage themselves in practicing speaking skills in the classroom in relation to their level of communicative competence. Accordingly, 95 (46.34\%) of them responded as they strongly agreed on the ideas that said I don't like to practice speaking since I am not perfect enough in English. In addition to this, $43.43 \%$ of the respondents also stated their feeling as they agreed on it. In general, among the given sampled respondents, $182(89.77 \%)$ of them, which were the majority of the respondents confirmed that they didn't want to practice speaking since they were not perfect enough in English. This implied that students were expecting themselves to be perfect enough in English in order to actively engage themselves in speaking. This kind of assumption makes the learners to be less motivated which couldn't make them fluent in speaking. But students speaking fluency would increase if they have high motivation from both students itself and the people around them.

However, some of the respondents, 9(4.4\%) of them expressed their feeling as they strongly disagreed on the expression which said I don't like to practice 
speaking since I am not perfect enough in English. Similar with this, 14 (6.83\%) of the respondents also stated their feeling as they disagreed on the given statement. This indicates that only few of the respondents were interested to practice in English though they were not perfect enough in English. In line with this, during classroom observation, the researcher observed as almost all of the students who were in the classroom were afraid of expressing their feeling easily in English. Due to this, it was clearly observed that students were afraid of sharing their ideas in English though the teacher was giving activities so as to enable them to interact with one another.

\section{Conclusions and Recommendations}

\subsection{Conclusion}

Following the findings of the study, conclusions were forwarded. These were:

The results of the study revealed that majority of the students were not motivated to speak in English during EFL sessions. As the finding of the study confirmed, most learners had no exposure of daily practicing speaking skills in the classroom. As a result, the study confirmed most students' resistance of teachers' trial to implement active learning methods in the classroom. In relation to the perception of the students towards the real practice of speaking skills in EFL sessions, students had a negative perception towards its implementation. Students' background, unwillingness of the students to speak and students' resistance of active learning techniques were the major factors that influenced the real practice of speaking during EFL sessions. The study also stated that most students were not active participant in the classroom due to fear of feedback given among their colleagues as well as teachers.

\subsection{Recommendations}

Based on the conclusions drawn, the following recommendations were forwarded to overcome the influencing factors of the real practice of speaking skills in EFL sessions.

- As the result of the study showed, majority of the students were not motivated to speak in English during EFL sessions. Hence, there were the resistances of students not to actively engage in the cooperative learning so as to share their ideas in English during teaching-learning process. In addition to this, it was also observed as most students had no interest and confidence to speak in English with their colleagues during the session. Therefore, the university as well as the teacher should create a good awareness among the students so as to enable them to share their ideas in English in their day to day activity.

- The teacher should develop the habit of using different active learning techniques in EFL classes in order to increase the exposure of our learners' engagement in sharing one's ideas in English.

- The study also stated that most students had a negative perception towards 
the implementation of active learning methods. Therefore, before implementing the different techniques of active learning, the teacher should play his/her own role to build the mind of the learners to positively perceive cooperative leaning i.e. the base of improving the proficiency of English.

- The students should be aware that making a mistake is part of learning. So that they shouldn't fear of feedback given during discussions. As a result, feedback, whether it is positive or negative, which might be given during delivery of the session in EFL, should be perceived positively.

- The concerned bodies should develop a good policies or strategies that enable all teachers to really create a conducive environment of practicing speaking in English. For instance, the classroom for language session should be manageable so as to encourage the real practice of speaking skills during EFL sessions. Furthermore, there should be a continuous follow up within the institution that can ensure as the teachers really employ the active involvement of the learners during delivery of the session. Finally, adequate training should also be given for students and teachers in order to train them on how to create a positive perception to implement the real practice of speaking skills during EFL sessions.

\section{Limitations of the Study}

This study focused only on College of Social Science and Humanities. As a result, the result of this study couldn't be generalized to other colleges. Furthermore, the study was concerned with the real practice of speaking skills during EFL session. So that the result of the study was limited to only language sessions rather than covering other courses.

\section{Conflicts of Interest}

The author declares no conflicts of interest regarding the publication of this paper.

\section{References}

Bozorgian, H. (2012). The Relationship between Listening and Other Language Skills in International English Language Testing System. Theory and Practice in Language Studies, 2, 657-663. https://doi.org/10.4304/tpls.2.4.657-663

Brown, H. D. (2000). Principles of Language Learning and Teaching (4th ed.). New York: Longman.

Celik, O., \& Yavuz, F. (2015). The Relationship between Speaking Grades and Listening Grades of University Level Preparatory Students. Procedia, 197, 2137-2140. https://doi.org/10.1016/j.sbspro.2015.07.339

Davies, D., \& Pearse, E. (2000). Success in English Teaching. Oxford: Oxford University Press.

Demissie, Y. (2007). Factors Affecting Speaking Skills. Unpublished MA Thesis, Haramaya: Haramaya University.

Gardner, H. (2006). Multiple Intelligences. New Horizons. New York: Basic Books. 
Gilakjani, A., \& Ahmadi, M. (2011). A Study of Factors Affecting EFL Learners' Comprehension and Strategies for Improvement. Journal of Language Teaching and Research, 2, 977-988. https://doi.org/10.4304/jltr.2.5.977-988

Horwitz, E. K., Horwitz, M. B., \& Cope, J. A. (1986). Foreign Language Classroom Anxiety. The Modern Language Journal, 70, 125-132. https://doi.org/10.1111/j.1540-4781.1986.tb05256.x

Kedir, A. (2017). Assessing the Factors That Affect Teaching Speaking Skills. International Journal of Humanities \& Social Science Studies, 3, 285-299. http://www.ijhsss.com

Larsen-Freeman (1986). Techniques and Principles in Language Teaching. Oxford: Oxford University Press.

Littlewood, W. (1981). Communicative Language Teaching: An Introduction. Cambridge: Cambridge University Press.

Muhammad, K. (2014). The Language Attitude of the Students of English Department Uin Sunan Kalijaga towards English. English Department of Faculty Adab and Cultural State Islamic University Sunan Kalijaga Yogyakarta.

Richards and Rodgers (2001). Approach and Methods in Language Teaching. Cambridge: Cambridge University Press. https://doi.org/10.1017/CBO9780511667305

Richards, J. C. (1990). The Language Teaching Matrix. New York: Cambridge University Press. https://doi.org/10.1017/CBO9780511667152

Rivers (1983). Interactive Language Teaching. Cambridge: Cambridge University Press.

Tamador, K., \& Snoubar, A. (2017). On the Relationship between Listening and Speaking Grades of AL-Balqa Applied University English as a Foreign Language Students. https://doi.org/10.5539/ies.v10n12p130

Tuan, N. H., \& Mai, J. N. (2015). Factors Affecting Students' Speaking Performance at LE Thanh High School. Asian Journal of Educational Research, 3, 8-23.

Urrutia, L. W. A., \& Vega, E. (2010). Encouraging Teenagers to Improve Speaking Skills through Games in Columbian Public School. Profile, 12, 11-31.

Yamane, T. (1967). Statistics: An Introductory Analysis (2nd ed.). New York: Harper and Row.

\section{Abbreviations and Acronyms}

EFL_English as a Foreign Language; and ESL_English as a Second Language. 